\title{
Trocholites Conrad, 1838 (Nautiloidea, Tarphycerida) in the Middle Ordovician of the Prague Basin and its palaeobiogeographical significance
}

\author{
ŠTĚPÁN MANDA
}

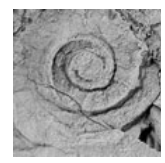

\begin{abstract}
Nautiloids of the order Tarphycerida are a characteristic component of warm-water Ordovician faunas of Baltica and Laurentia but are usually absent from the cooler high latitude marine environments. The presence of the tarphycerid Trocholites, reported from the Middle Ordovician, Dobrotivian (late Darriwilian) strata of the Iberian Chain and Armorican Massif (peri-Gondwanan Europe), provide an exception. Lituites primulus Barrande, 1865, represented by a single poorly-preserved individual was reported from coeval strata in the Prague Basin (Perunica) and doubtfully assigned to Curtoceras or Trocholites. New biostratigraphicaly well-constrained specimens of Trocholites described and discussed from the early Dobrotivian of the Prague Basin, are conspecific with Trocholites fugax previously described from the Iberian Chain and Armorican Massif. The contemporaneous presence of Trocholites fugax in Perunica and peri-Gondwanan terranes is additional evidence for faunal connections between these microcontinents during the Dobrotivian. By comparison with the preceding Llanvirnian (early Darriwilian) fauna, the low diversity Dobrotivian cephalopod fauna of the Prague Basin suggests an increasing faunal separation between Perunica and Baltica. The occurrence of Trocholites in early Dobrotivian strata of Perunica, the Iberian Chain and Armorican Massif reflects an unusual dispersion event of tarphycerids into lower latitude seas coinciding with a distinct climate perturbation during the Ordovician. $\bullet$ Key words: Middle Ordovician, Dobrotivian, Darriwilian, Cephalopoda, Tarphycerida, taxonomy, Prague Basin.
\end{abstract}

MANDA, Š. 2008. Trocholites Conrad, 1838 (Nautiloidea, Tarphycerida) in the Middle Ordovician of the Prague Basin and its palaeobiogeographical significance. Bulletin of Geosciences 83(3), 327-334 (4 figures, 1 table). Czech Geological Survey, Prague. ISSN 1214-1119. Manuscript received August 11, 2008; accepted in revised form September 1, 2008, issued September 30, 2008.

Štěpán Manda, Czech Geological Survey, Klárov 3, P.O.B. 85, 11821 Praha 011, Czech Republic; manda@cgu.cz.

The Ordovician cephalopod fauna of the Prague Basin was described by J. Barrande in his classic "Systême silurien $d u$ Centre de la Bohême” (1865-1877). Barrande erected 35 species of Orthoceras Bruguière, 1789, two species of Bathmoceras Barrande, 1867, three species of Endoceras Hall, 1847, and a single species each of Tretoceras Salter, 1858, Bactrites Sandberger, 1843, Gomphoceras Sowerby, 1839 (in Murchison 1939), and Lituites Bertrand, 1763. Despite continual and intensive research on the Ordovician strata of the Prague Basin since Barrande's time, only a single new cephalopod species has been added (Marek 1999). This suggests that our knowledge of the Ordovician cephalopod fauna of the Prague Basin is relatively complete. Dzik (1981) synonymized Tretoceras parvulum Barrande, 1868 with Bactroceras sandbergeri (Barrande, 1868); see also Hewitt \& Stait (1985) and Evans (2005). Marek (1999) suggested that Bathmoceras complexum (Barrande, 1856) is conspecific with Bathomoceras praeposterum Barrande, 1867. Many researches have provided information about the stratigraphic ranges of Barrande's species (for example Prantl 1952; Havlíček \& Vaněk 1966; Mergl 1978; Kraft \& Kraft 1990, 1993, 1994; Budil 1999), although the identity of certain taxa is in need of revision. The last short summary of cephalopod distribution in the Ordovician of the Prague Basin was published by Marek (1999).

As a rule, cephalopods are rather uncommon in the Ordovician of the Prague Basin. The fauna usually consists of one species or a few taxa of orthocone cephalopods belonging to the orders Orthocerida and Pseudorthocerida (and where unrevised, commonly referred to the genus Orthoceras). Ellesmerocerids are known from the Klabava Formation (Arenigian; Dapingian-earliest Darriwilian), the Šárka Formation (early Darriwilian; latest Arenigian-Llanvirnian) and the Králův Dvůr Formation (Kralodvorian; early Hirnantian). Endocerids and a single actinocerid are restricted to the Šrka Formation. A single oncocerid shell has been described from the Králův Dvůr Formation (see Marek 1999). 
Tarphyceratids are known only from the Dobrotivá Formation (Dobrotivian, late Darriwilian). Barrande (1865) described a single poorly-preserved shell, assigning it to "Lituites" primulus. Klouček (1909), Vaněk (1999), and Marek (1999) all referred to the presence of "Lituites" primulus or Curtoceras, respectively, but without providing descriptions. This paper describes a suite of newly-collected specimens regarded as belonging to Trocholites fugax Babin \& Gutiérrez-Marco, 1992. The occurrence of tarphycerids in the low diversity cephalopod fauna of the early Dobrotivian is of palaeobiogeographic significance because they are only known from Perunica and peri-Gondwanan Europe during Dobrotivian time (e.g., Babin et al. 1996, Bogolepova 1999).

The order Tarphycerida Flower, 1950 includes nautiloids with a bilaterally symmetrical, evolute or convolute shell and a relatively thick siphonal tube. Lithuitids originally grouped together with tarphyceratids (see Flower 1950, Furnish \& Glenister 1964) in fact comprise an independent clade "Lituitina" Dzik, 1984 within the Orthoceratoidea Khun, 1940 (see Dzik 1981, 1984). In addition, some authors considered the order Barrandeocerida Flower, 1950 as a suborder within the Tarphycerida (see Turek 2008), but more data concerning early ontogeny and structure of the siphuncle are needed. Tarphyceratids appeared during the latest early Ordovician and their diversity rapidly reached its maximum just before the Middle Ordovician (Frey et al. 2004). During the Ordovician tarphycerids inhabited shallow and warm seas of carbonate platforms, e.g., Baltica, Laurentia, and Kazakhstania. The end-Ordovician extinction event reduced the diversity of the Tarphycerida, and the few surviving clades became extinct during the Silurian (for summary see Dzik 1984, Stridsberg \& Turek 1997). The tightly-coiled nautiliconic shell of tarphyceratids suggests that they might have been active swimmers (see Westermann 1998).

\section{Cephalopod distribution in the Middle Ordovician of the Prague Basin}

The Middle Ordovician sequence of the Prague Basin is divided into the Klabava, Śárka and Dobrotivá formations. In the classic concept (for summary see Havlíček 1998), the Klabava Formation corresponds with the Arenigian-earliest Llanvirnian, the Śarka Formation with the Llanvirnian and the Dobrotivá Formation with the Dobrotivian. The recent international division of the Middle Ordovician does not fit well with the British and Mediterranean stages and the correlation of Bohemian to international remains unclear. Following the concept of P. Kraft and O. Fatka and presented by various authors (see Kraft \& Fatka 1999), the Middle Ordovician is here taken to have started within the Klabava Formation and ended close to the boundary between the Dobrotivá and Libeň formations.

\section{Klabava Formation: Arenigian-earliest Llanvirnian (Dapingian-earliest Darriwilian)}

Cephalopods appear in the Prague Basin at the beginning of the Middle Ordovician in the upper part of the Klabava Formation, which consists mainly of yellow-grey and reddish shales. Two indeterminable species of orthocone cephalopods and the ellesmerocerid Bathmoceras complexum (Barrande, 1856) have been reported from the shales of the Holograptus tardibrachiatus Zone, Arenigian, Dapingian (Kraft \& Kraft 1993, Marek 1999). The ellesmerocerid Bactroceras cf. sandbergeri (Barrande, 1867), and lituitid Rhynchorthoceras cf. angelini (Boll, 1857) occur rarely in the shales and tuffites of the succeeding Azygograptus ellesi-Tetragraptus reclinatus abbreviatus Zone (Kraft \& Kraft 1994, Marek 1999). The appearance of ellesmerocerid and lituitid genera in the upper Klabava Formation is considered to be a refection of the initiation of communication between Perunica and Baltica during the late Arenigian (Frýda 1988, Mergl 1991, Frýda \& Rohr 1999). Dzik (1983) pointed out that the conodont fauna of the late Klabava Formation contains some Baltic taxa although diversity is low in comparison with Baltica probably due to cold water conditions (see also Zusková 1993). The same distribution pattern is exhibited amongst trilobite and gastropod faunas as well as cephalopod faunas.

\section{Šárka Formation: Llanvirnian (early Darriwilian)}

The Šarka Formation (Llanvirnian; early Dariwillian) consists mainly of dark shales and contains the most diverse cephalopod fauna in the Ordovician of the Prague Basin. Cephalopods have been collected mainly from siliceous nodules in the Rokycany and Praha town areas. The most common material consists of orthoconic cephalopods belonging to the orders Orthocerida and Pseudorthocerida, which need to be revised. The ellesmerocerids Bactroceras sandbergeri (Barrande, 1867) (including Tretoceras parvulum Barrande, 1868, see Dzik 1984) and Bathmoceras complexum (Barrande, 1856) (including Bathmoceras praeposterum Barrande, 1867, see Marek 1999) are less common. Endocerids are represented by three rare species: $\mathrm{Va}$ ginoceras novator (Barrande, 1870), Cameroceras peregrinum (Barrande, 1870) and "Endoceras" conquassatum Barrande, 1870 (see Marek 1999). The single actinocerid species "Orthoceras" bonum is also rare (Marek 1999). The presence of ellesmerocerids, endocerids and actinocerids reflects a period of enhanced faunal exchange between Baltica and Perunica during the Llanvirnian (Marek 1999). The cephalopod fauna of the Śarka Formation exhibits the strongest affinity within the Ordovician sequence of the Prague Basin with Baltic cephalopod faunas (e.g., Holm 1899a, b; Balashov 1968). By contrast, the 


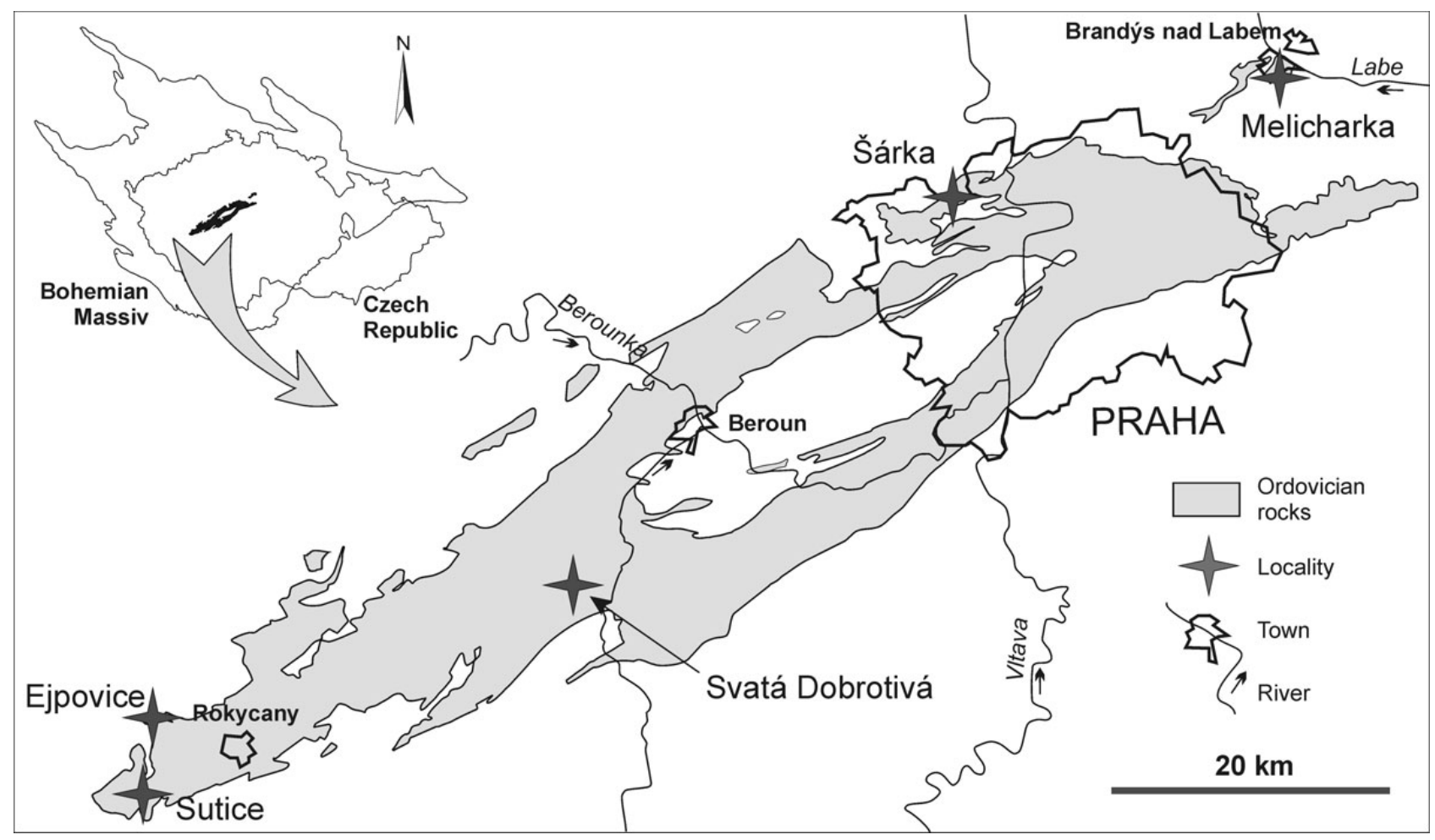

Figure 1. Distribution of the Ordovician rocks in the Prague Basin, Czech Republic and the location of Trocholites-bearing localities.

benthic fauna that consists of trilobites and brachiopods shows only weak affinities with Baltic assemblages (Havlíček et al. 1994).

\section{Dobrotivá Formation: Dobrotivian (late Darriwilian)}

The Dobrotivá Formation is developed as black shales similar to those of the underlying Śarka Formation. The two formations differ in the nature of their faunal communities rather than facies. The cephalopod fauna of the Dobrotivá Formation is reduced in diversity by comprison with the Śarka Formation. The Baltic genera represented in the Śarka Formation are missing from the Dobrotivá Formation. Three rare species of longiconic orthocerids occur in siliceous nodules and more rarely in shale (Klouček 1909, Havlíček \& Vaněk 1966). In addition, Barrande (1865) described a poorly-preserved portion of a coiled shell from the Svatá Dobrotivá (Sancta Benigna) locality as Lituites primulus Barrande, 1865 (see Fig. 2). Klouček (1909) also reported Lituites primulus from the Śárecké Valley at Praha and Vaněk (1999) listed "Lituites" primulus from siliceous nodules from the lower part of the Dobrotivá Formation at locality Melicharka in Brandýs nad Labem Town. An additional specimen was reported by Mergl (1996) from a shale of the Hustedograptus teretiusculus Zone at Ejpovice Village (Fig. 1).

\section{Palaeobiogeographical significance of Trocholites}

Tarphycerid nautiloids originated in the late Early Ordovician and form a characteristic component of Middle to Upper Ordovician cephalopod faunas, inhabiting warm-water carbonate platforms (for summary see Furnish \& Glenister 1964, Dzik 1984). Thus tarphycerids may be considered as an indicator of warm-water masses or might suggest connections with such water bodies. Trocholites Conrad, 1838 including 42 species is widely distributed in Middle and Upper Ordovician strata of Baltica, South and North China, Tibet, Laurentia, and Australia (for summary see Schröder 1891, Whiteaves 1904, Chen \& Liu 1976, Dzik 1984, Stait et al. 1985, Babin \& Gutiérrez-Marco 1992 and Guo 1998).

Havlíček et al. (1994, p. 37) emphasized the "absolute difference in benthic and necto-benthic association" between Baltica and Perunica during the Dobrotivian. According to Havlíček et al. (1994), Tornquist's Ocean “functioned as an effective barrier" during Dobrotivian times. Kraft \& Kraft (1990) and Fatka et al. (1998) described a single specimen of the Baltic graptolite Gymnograptus linnarsoni (Moberg, 1896) from the Hustedograptus teretiusculus Zone of the Prague Basin. The presence of Trocholites in the Prague Basin further suggests a degree of connection with Baltica during the Hustedograptus teretiusculus Zone. The presence of Trocholites in early Dobrotivian contrasts with the absence of any other 


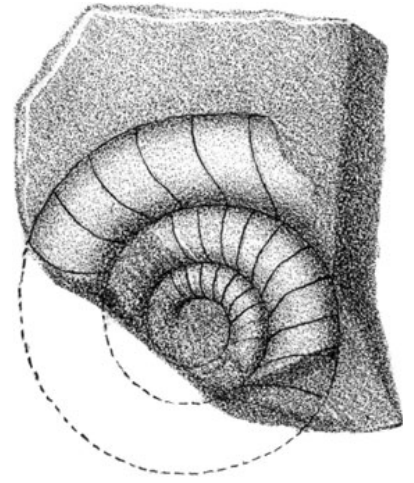

A

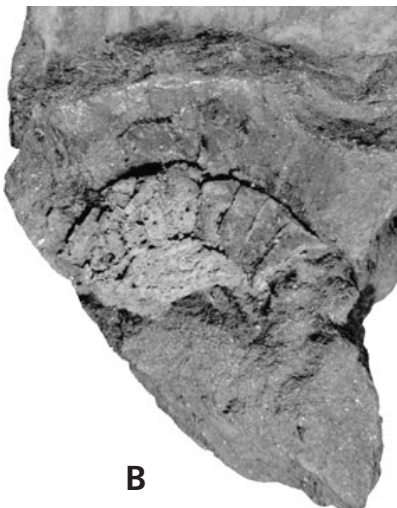

Figure 2. "Lituites primulus" Barrande, 1865; holotype by monotypy. Svatá Dobrotivá (Sancta Benigna) d1 locality. Most probably Middle Ordovician, lower Dobrotivian, Dobrotivá Formation. • A - reproduction of a specimen illustrated by Barrande (1865) on pl. 99 as fig. $12, \times 1.2$. -B - the same specimen, lateral view, $\times 1$.2. National Museum, L 40460.

cephalopod genus shared with Baltica during this time as well as the absence of tarphycerids in the underlying Llanvirnian where five Baltic genera are present.

Trocholites fugax was described by Babin \& Gutiérrez-Marco (1992) from the early Dobrotivian of Spain. Babin et al. (1996) described the same species from the Dobrotivian of the Armorican Massif. Thus the presence of Trocholites fugax in the Prague Basin, Iberian Chain and Armorican Massif are coeval, suggesting that faunal exchange took place between these areas during the early Dobrotivian, which is in agreement with the conclusions of Havlíček et al. (1994). More recently Ausich et al. (2002) described a Dobrotivian echinoderm fauna from the Iberian Chain and suggested that there was faunal isolation between peri-Gondwana and Perunica. In addition, Evans (2000) noted the presence of Trocholites even in the Middle Ordovician of Bolivia, Northwestern Gondwana, but this material has not yet been described nor figured.

\section{Conclusions}

The appearance of the coiled tarphycerid Trocholites fugax in the early Dobrotivian of Perunica and peri-Gondwana seem to reflects an unusual dispersion event of tarphycerids to higher latitudes (Fig. 4). It suggests that isolation between Baltica and Perunica was not absolute, as was previously stated. Havlíček et al. (1994) explained the isolation between the Prague Basin and Baltica through enhanced surface currents of Tornquist's Sea. However, there is no reason why such currents should have confined faunal exchange. Contrarily, faunal isolation would be more likely where surface current activity is low, leading to prolonged transport of invertebrate larvae and the higher pro- bability of their mortality. With more occasional instability common in weak currents, this would cause mass mortality of the larvae. Babin \& Gutiérrez-Marco (1992) proposed that the presence of Trocholites in Spain during the early Dobrotivian might be explained by a prolonged period of climatic disturbance in which storm systems that developed in temperate palaeolatitudes in the vicinity of Baltica, transferred bodies of water carrying planktic and nektonic animals southward onto peri-Gondwana.

The nektonic habit of Trocholites is clearly suggested by its small nautiliconic shell (see Westerman 1998). In addition, the very small size of the embryonic shell of Trocholites might indicate the planktotrophy of the early post-hatching stage. Evans (2000) studied an Ordovician cephalopod fauna from Saudi Arabia that included warm-water elements, i.e. northern shelf of Gondwana, using the hypothesis of Babin \& Gutiérrez-Marco (1992) to explain their presence there. The occurrence of Trocholites fugax in the Prague Basin also appears to support this hypothesis.

\section{Systematic palaeontology}

Subclass Nautiloidea Agassiz, 1847

Order Tarphycerida Flower, 1950 (in Flower \& Kummel 1950)

Family Trocholitidae Chapman, 1857

\section{Genus Trocholites Conrad, 1838}

Type species. - Trocholites ammoinius Conrad, 1838.

\section{Trocholites fugax Babin \& Gutiérrez-Marco, 1992} Figure 3A-E

?1865 Lituites primulus Barr.; Barrande, pl. 99, fig. 12.

1992 Trocholites fugax n. sp.; Babin \& Gutiérrez-Marco, pp. 530-534, figs 3a-h, 4a-f. See for further synonymy of Spanish material.

?1992 Lituites primulus. - Babin \& Gutiérrez-Marco, p. 534.

1996 Trocholites fugax. - Babin et al., p. 107, pl. 1, figs $1-3$.

1996 “cyrtokonní nautiloid”. - Mergl, p. 32.

1999 “Lituites" primulus Barrande. - Vaněk, p. 8.

?1999 Curtoceras primulus. - Marek, pp. 415, 416.

Holotype. - Specimen No. NE VII 2639 (Museo GeoMinero, Madrid) designated by Babin \& Gutiérrez-Marco (1992) and figured by them as fig. 3D. Middle Ordovician, early Dobrotivian. Navas de Estena, Massif Hesperian, Spain.

Material. - Seven more or less flattened shells preserved in shale: specimens No. 11484, 11518, 11521, 11560, 11664, 

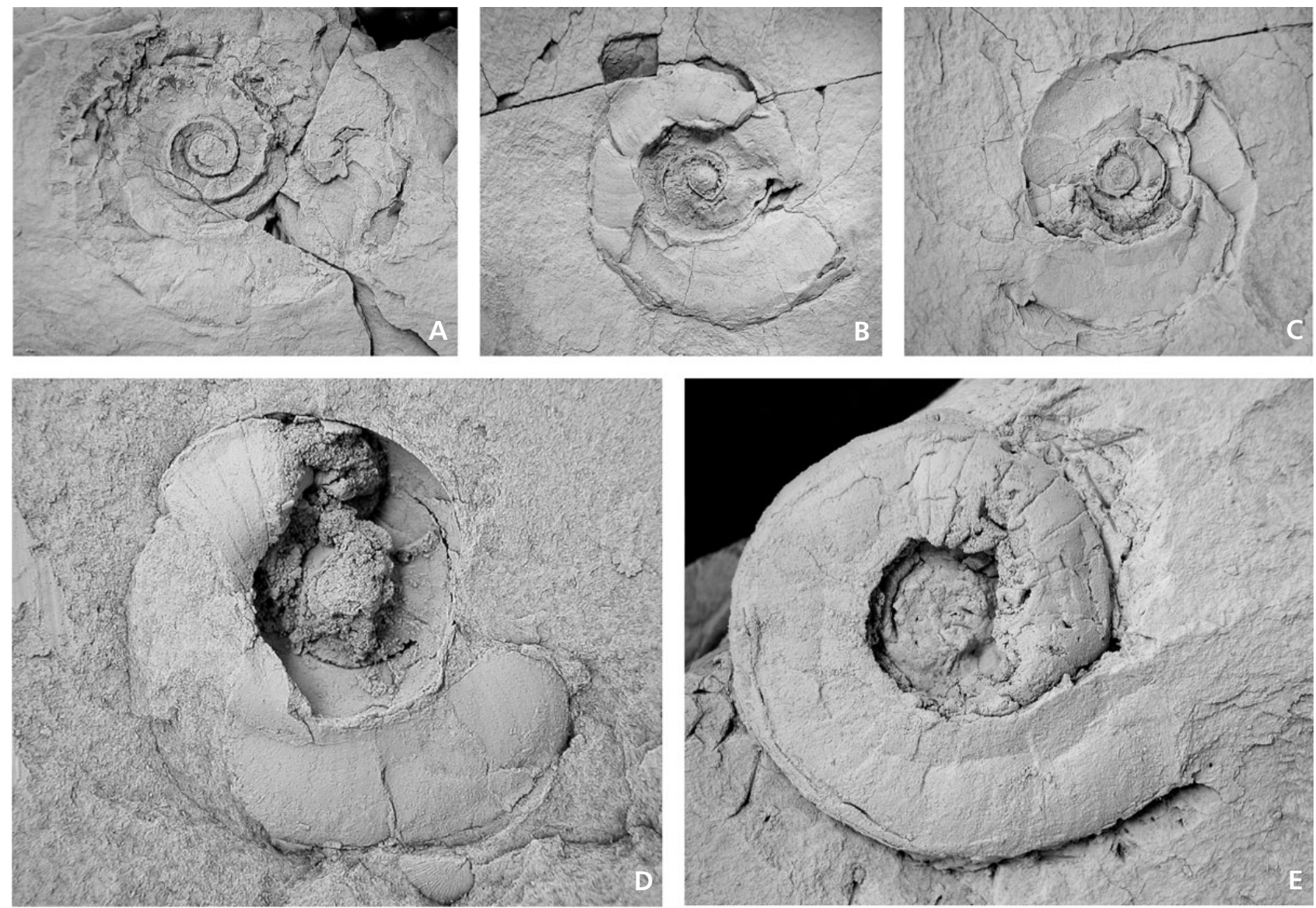

Figure 3. Trocholites fugax Babin \& Gutiérrez-Marco, 1992. Prague Basin, Ordovician, Middle Ordovician, lower Dobrotivian. Dobrotivá Formation. - A - Tymákov, Sutice 1, western slope, lateral view, × 1.4, specimen No. 11675, collection of M. Mergl, Museum of Doctor Bohuslav Horák, Rokycany. - B - Tymákov, Sutice 1, western slope, lateral view, × 1.3, specimen No. 11518, collection of M. Mergl, Museum of Doctor Bohuslav Horák, Rokycany. - C-Tymákov, Sutice 1, western slope, lateral view, × 1.2, specimen No. 11484, collection of M. Mergl, Museum of Doctor Bohuslav Horák, Rokycany. - D - Ejpovice, Ejpovice, northern slope of Čilina Hill, lateral view, × 1.8, CGS MM 517a. • E - Tymákov, Sutice 1, western slope, lateral view, × 2.3, specimen No. 11521, collection of M. Mergl, Museum of Doctor Bohuslav Horák, Rokycany. All specimens are coated with ammonium chloride.

11675 are housed in the Museum of Doctor Bohuslav Horák in Town of Rokycan, West Bohemia; specimen MM $517 \mathrm{a}, \mathrm{b}$ is deposited in the Czech Geological Survey, Praha, Collection of M. Mergl. Two additional unnumbered specimens are housed in the private collection of O. Karoušek.

Description of the Bohemian material. - Gradually expanding exogastric convolutedly coiled shells. Whorl cross section depressed and rounded across the venter and flanks. Siphuncle dorsal and submarginal, its diameter is about $0.5 \mathrm{~mm}$ where the lateral diameter of the shell is about $6 \mathrm{~mm}$. Body chamber long, about two-thirds of a volution. Cameral depth is about $1 / 3-1 / 4$ of the dorsoventral diameter of the whorl. Sutures are poorly preserved, probably almost straight with weak dorsal lobe. First three whorls exhibit almost straight, densely-packed growth lines that later become irregular and more distant. Hyponomic sinus is shallow and broad. Approximately five whorls are developed. Embryonic shell is not visible, but must be very small with a diameter less than $0.5 \mathrm{~mm}$. Dimensions are giving in Table 1.

Discussion. - Barrande (1865, pl. 99 as fig. 12) first illustrated Lituites primulus as a new species (holotype by monotypy, see Fig. 2). This type specimen is a small part of a convolute phragmocone with three whorls preserved in a slightly flattened state in dark shale. As noted by Babin \& Gutiérrez-Marco (1992), the preservation of the specimen figured by Barrande as Lituites primulus excludes a precise comparison with better-preserved specimens showing more diagnostic features. The mode of coiling and the depth of the camerae are similar to that of Trocholites fugax. The holotype of Lituites primulus came from the Svatá Dobrotivá - Sancta Benigna d1 locality, the exact site of which is unknown. However, the brachiopods and trilobites described by Barrande from this locality clearly suggest a Dobrotivian age, and the lithology of the matrix is similar 


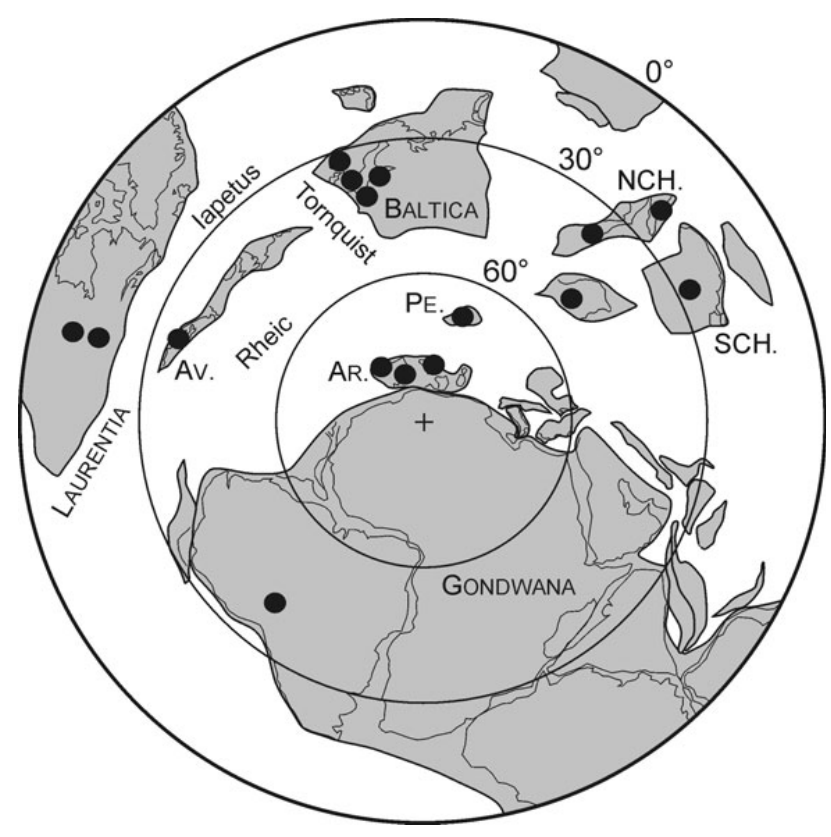

Figure 4. Distribution of Trocholites in the Middle Ordovician. Palaeogeographic reconstruction adopted from Cocks \& Torsvik (2002). For data see Schröder (1891), Chen \& Liu (1976), Dzik (1984), Babin \& Gutiérrez-Marco (1992), Babin et al. (1996), and Frey (1995). Abbreviations: Ar. - Armorica, Av. - Avalonia, NCH. - North China, SCH. South China, Pe. - Perunica.

Table 1. Dimensions of Trocholites fugax. Abbreviations: dv-diameter of shell (ventral), dd - diameter of shell (dorsal), wh - whorl height, uw umbilical width (diameter of whorl), $\mathrm{n}$ - number of visible whorls. All measurements are in $\mathrm{mm}$.

\begin{tabular}{lllrll}
\hline Specimen & dv & dd & wh & uw & n \\
\hline MM 517 & 24 & 21 & 8 & 11.5 & 5 \\
11484 & 30 & 25.5 & 10 & 12 & 5 \\
11518 & 29 & 24 & 11 & 14 & 5 \\
11521 & 27 & 21 & 8 & 10.5 & 4 \\
11560 & 19 & 16 & 5 & 9 & 4 \\
11664 & 13 & 12 & 4 & 8 & 4 \\
11675 & 30.5 & 26.5 & 12 & 14 & 5 \\
\hline
\end{tabular}

to that of the Dobrotivá Formation. This suggests that Trocholites fugax and Lituites primulus are coeval and probably conspecific, but the poor preservation of the holotype of the latter leaves some uncertainty as to this and therefore the type species is not proposed as a senior synonym of Trocholites fugax.

Occurrence. - Dobrotivian of Spain and the Armorican Massif, France (Babin \& Gutiérrez-Marco 1992; Babin et al. 1996).

Prague Basin (Bohemia): Middle Ordovician, early Dobrotivian (early Llandeillan, late Darriwilian), Hustedograptus teretiusculus Zone. Lower Dobrotivá Formation.
1. Ejpovice, northern slope of Čilina Hill, W of Rokycany Town, West Bohemia; black shale with brachiopods, conularids, graptolites, bivalves, hyolithids, orthocone cephalopods, trilobites, machaerids, ostracods and echinoderms (for detail of fossil contents see Mergl 1996); single specimen was collected by M. Mergl.

2. Tymákov, Sutice 1, western slope, West Bohemia, dark grey shale with numerous trilobites and brachiopods (see Mergl 1978); all available specimens were collected by M. Mergl.

3. Melicharka, field at Melicharka factory, Brandýs nad Labem, Central Bohemia; shale with small siliceous nodules rich in trilobites, brachiopods, graptolites, orthocone cephalopods, conularids, bivalves and echinoderms (for detailed descriptions see Vaněk 1999); two specimens of Trocholites are present in private collection of O. Karoušek from Brandýs nad Labem.

\section{Acknowledgments}

Special thanks are given to Michal Mergl from the University of West Bohemia, Plzeň who kindly lend me specimens from his collection. Many thanks to David H. Evans (Natural England, Peterborough), Vojtěch Turek (National Museum, Prague) and Susan Turner (Queensland Museum, Brisbane) for the help with the critical reading of the manuscript and for language corrections. Vojtěch Turek also kindly gave access to Barrande's collection. This paper is contribution to the UNESCO-IUGS IGCP Project 503 "Ordovician Palaeogeography and Palaeoclimate". The work was supported by the project VaV DE08P04OMG002 (Czech Republic Ministry of Culture).

\section{References}

AgASSIZ, L. 1847. An introduction to the study of Natural history, in a series of lectures delivered in the hall of the College of Physicians and Surgeons. 58 pp. Greeley \& McElrath, New York.

Ausich, W., GIL CID, D. \& Alonso, D.P. 2002. Ordovician (Dobrotivian (Llandeillian Stage) to Ashgill) crinoids (Phyllum Echinodermata) from Montes de Toledo and Sierra Morena, Spain with implications for paleogeography of periGondwana. Journal of Paleontology 76(6), 975-992.

DOI 10.1666/0022-3360(2002)076<0975:ODLSTA>2.0.CO;2

BABIN, C. \& GUTIÉRREZ-MARCO, J.C. 1992. Intérêt paléobiogéographique de la presence du genere Trocholites (Cephalopoda, Nautiloidea) dans le Dobrotivá (Llandeilo) inférieur d'Espagne. Neues Jahrbuch für Geologie und Paläontologie, Monatshefte 1992(9), 519-541.

Babin, C., BeCQ-Giraudon, J.F., LARdeuX, H. \& GuTIÉRREZ-MARCO, J.C. 1996. Présence de Trocholites (Cephalopoda, Nautiloidea) dans L'Ordovicien du Massif Armoricain et du Portugal. Bulletin de la Société des Sciences de l'Ouest de la France, nouvelle série 18(3), 105-112. 
BALASHOV, Z.G. 1968. Ordovician Endoceratoidea of the U.S.S.R. 170 pp. University of Leningrad Press, Leningrad.

BARRANDE, J. 1856. Bemerkungen über einige neue Fossilien aus der Umgebung von Rokitzan im silurischen Becken von Mittel-Böhmen. Jahrbuch der kaiserlich-königlichen geologischen Reichsanstalt 7, 355-360.

BARRANDE, J. 1865-1877. Systême silurien du Centre de la Bohême, Ière partie: Recherches Paléontologiques, vol. II, Classe de Mollusques, Ordre des Céphalopodes, 1865, ser. 6, pl. 1-107; 1866, ser. 7, pl. 108-244; 1867, ser. 1, 712 pp.; 1868, ser. 8, pl. 245-350; 1870, ser. 2, 266 pp., ser. 9, pl. 351-460; 1874, ser. 3, 804 pp.; 1877, ser. 4, 742 pp., ser. 5, 743 pp., supplement 1, 297 pp., supplement 2, pl. 461-544. Privately published, Prague \& Paris.

BERTRAND, E. 1763. Dictionnaire universel des fossiles propres, et des fossiles accidentels. 606 pp. Louis Chambeau, Avignon.

BogOLEPOVA, O.K. 1999. Ordovician cephalopods and linguate brachiopods from the Southern Alps: remarks on palaeogeography. Acta Universitatis Carolinae, Geologica 43(1-2), 409-411.

BOLL, E. 1857. Beitrag zur Kenntnis der silurischen Cephalopoden im norddeutschen Diluvium und den anstehenden Lagern Schwedens. Archiv des Vereins der Freunde der Naturgeschichte in Mecklenburg 11, 58-95.

BRUGiÈre, J.G. 1789. Encyclopedie methodique. Histoire naturelle des vers. Vol. 1, pt. 1.757 pp. Panckoucke, Paris \& Liège.

BuDIL, P. 1999. Nový výchoz dobrotivského souvrství v Praze-Vokovicích (střední ordovik. Journal of the Czech Geological Society 44(1/2), 195-199.

CHAPMAN, E.J. 1857. On the occurrence of the genus Cryptoceras in Silurian rocks. Canadian Journal, new series 2, 264-268.

CHEN, J.Y. \& LIU, G.W. 1976. Ordovician nautiloids. Memoirs of the Nanjing Institute of Geology and Palaeontology 7, $42-53$.

COCKS, L.R.M. \& TORSVIK, T.H. 2002. Earth geography from 500 to 400 million years ago: a faunal and palaeomagnetic review. Journal of the Geological Society 159, 631-644. DOI $10.1144 / 0016-764901-118$

CONRAD, T.A. 1838. Report on the Palaeontological Department of the Survey (New York). New York State Geological Survey, Annual Report 2, 107-119.

DZIK, J. 1981. Origin of the Cephalopoda. Acta Palaeontologica Polonica 26(2), 161-191.

DZIK, J. 1983. Early Ordovician conodonts from the Barrandian and Bohemian-Baltic faunal relationship. Acta Palaeontologica Polonica 28(3-4), 327-368.

DZIK, J. 1984. Phylogeny of the Nautiloidea. Paleontologia Polonica 45, 1-255.

Evans, D.H. 2000. A cephalopod fauna from the Middle Ordovician of Saudi Arabia. Palaeontology 43(3), 573-589. DO1 10.1111/j.0031-0239.2000.00141.x

EvANS, D.H. 2005. The Lower and Middle Ordovician Cephalopods of England and Wales. Monograph of the Palaeontographical Society 158, 1-88.
FATKA, O., KRAFT, J. \& KRAFT, P. 1998. Occurence of selected "Baltic" graptolites in peri-Gondwana and associated microfossils. Zprávy o geologických výzkumech v roce 1997, $80-83$.

Flower, R.H. 1950. In FlOwer, R.H. \& KumMel, B. 1950. A classification of the Nautiloidea. Journal of Paleontology 24(5), 604-616.

FREY, R.C. 1995. Middle and Upper Ordovician nautiloid cephalopods of the Cincinnati Arch region of Kentucky, Indiana, and Ohio. United States Geological Survey Professional Paper 1066-P, 1-171.

FreY, R.C., Beresi, M.S., Evans, D.H., KING, A.H. \& PERCIVAL, I.G. 2004. Nautiloid cephalopods, 209-213. In Webby, B.D., PARIS, F., Droser, M.L. \& Percival, I.G. (eds) The Great Ordovician Biodiversification Event. Columbia University Press, New York.

FRÝDA, J. 1988. A new species of Modestospira (Gastropoda) from the Ordovician of Bohemia. Věstník Ústredního ústavu geologického 63(4), 227-232.

FRÝDA, J. \& ROHR, D.M. 1999. Taxonomy and Paleobiogeography of the Ordovician Clisospiridae and Onychochilidae (Mollusca). Acta Universitatis Carolinae, Geologica 43(1-2), 405-408.

FURNISH, W.M. \& GLENISTER, B.F. 1964. Nautiloidea Tarphycerida, K343-K368. In MoORE, R.C. (ed.) Treatise on Invertebrate Paleontology, Part K, Mollusca. Geological Society of America, Lawrence.

GuO, D. 1998. New materials of Ordovician cephalopods from Zuozishan district, Inner Mongolia, $\mathrm{N}$ China. Acta Palaeontologica Sinica 37, 344-351.

HALL, J. 1847. Natural history of New York, Paleontology, vol.1, containing descriptions of the organic remains of the lower division of the New-York system (equivalent of the Lower Silurian rocks of Europe). 338 pp. Van Benthuysen \& New York Geological Survey, New York.

HAVLíČEK, V. 1998. Ordovician, 39-79. In CHLUPÁČ, I., HAVLíČEK, V., KŘÍŽ, J. \& ŠTORCH, P. Palaeozoic of the Barrandian (Cambrian to Devonian). Czech Geological Survey, Prague.

HAVLÍČEK, V. \& VANĚK, J. 1966. The biostratigraphy of the Ordovician of Bohemia. Sborník geologických věd, Paleontologie 8, 7-69.

HAVlíčEK, V., VANĚK, J. \& FATKA, O. 1994. Perunica microcontinent in the Ordovician (its position within Mediterranean Province, series division, benthic and pelagic asociation). Sborník geologických věd, Geologie 46, 23-56.

HewITT, R.A. \& STAIT, B. 1985. Phosphatic connecting rings and ecology of an Ordovician ellesmerocerid nautiloid. Alcheringa 9, 229-243. DOI 10.1080/03115518508618970

HoLM, G. 1899a. Om att par Bactrites-liknande Untersiluriska Orthocerformer. Geologiska Föreningen Förhandlingar 20, 354-360.

Holm, G. 1899b. Om Bathmoceras. Geologiska Föreningen Förhandlingar 21, 271-305.

KuHN, O. 1940. Paläozoologie in Tabellen. 50 pp. Fischer Verlag, Jena.

KLOUČEK, C. 1909. Předběžná zpráva o dvou různých hori- 
zontech v pásmu $\mathrm{D}_{1}$. Věstník Královské české společnosti nauk, Třída matematicko-př́rodovědná 1908(20), 1-4.

KRAFT, P. \& FATKA, O. Eds 1999. Quo vadis Ordovician? Acta Universitatis Carolinae, Geologica 43(1-2), 1-534.

KRAFT, J. \& KRAFT, P. 1990. Some new and lesser-known Ordovician localities in the western part of the Prague Basin. Folia Musei Rerum Naturalium Bohemia Occidentalis, Geologica 31, 3-24.

KrAFT, J. \& KRAFT, P. 1993. The Holograptus tardibrachiatus Biozone (Klabava Formation, Ordovician of the Prague Basin). Folia Musei Rerum Naturalium Bohemia Occidentalis, Geologica 37, 1-35.

KrAFT, J. \& KRAFT, P. 1994. The Azygograptus-Tetragraptus (reclinatus group) Biozone (Klabava Formation, Ordovician of the Prague Basin). Folia Musei Rerum Naturalium Bohemia Occidentalis, Geologica 40, 1-36.

MAREK, J. 1999. Ordovician cephalopods of the Prague Basin: a review. Acta Universitatis Carolinae, Geologica 43, 413-416.

MERGL, M. 1978. Výsledky paleontologického výzkumu ordoviku v širším okolí Starého Plzence. Sborník Západočeského muzea, Př́rodní vědy 28, 1-70.

MERGL, M. 1991. New Lower Ordovician (Arenig) trilobite assemblages in Bohemia. Časopis pro mineralogii a geologii 36(4), 193-203.

MERGL, M. 1996. Lower Ordovician in temporary outcrops along highway D5 near Mýto and Ejpovice (West Bohemia). Erica $5,21-26$.

MOBERG, J.C. 1896. Geologisk vägvisare inom Fogelsångstrakten angifvande läget och geologiska åldern af dervarande observations-punkter för fasta berggrunden. Meddelanden från Lunds Geologiska Fältklubb 2, 1-36.

MURCHISON, R.I. 1839. The Silurian System, founded on geological researches in the counties of Salop, Hereford, Padnor, with descriptions of the coal fields and overlying formations. Part 1. 768 pp. John Murray, London.
PRANTL, F. 1952. Zkameněliny českých pramoři. 321 pp. Vesmír, Praha.

SALTER, J.W. 1858. On a new genus of Cephalopoda, Tretoceras (Orthoceras bisiphonatum Sowerby), and the occurrence of the genus Ascoceras Barrande in Britain. Quarterly Journal of the Geological Society of London 14, 179.

SANDBERGER, G. 1843. Allgemeine Schilderung der paläontologischen Verhältnisse der älteren Formationen Nassaus. Amtlicher Bericht über die Versammlung der Deutschen Naturforscher und Ärzte zu Mainz 20, 154-160.

SCHRÖDER, H. 1891. Untersuchungen uber silurische Cephalopoden. Palaeontologische Abhandlungen Neue Floge 1(4), $1-48$.

Stait, B., WebBy, B.D. \& Percival, I.G. 1985. Late Ordovician nautiloids from Central New South Wales, Australia. Alcheringa 9, 143-157. DOI 10.1080/03115518508618962

STRIDSBERG, S. \& TUREK, V. 1997. A revision of the Silurian nautiloid genus Ophioceras Barrande. Geologiska Föreningen Förhandlingar 119, 21-36.

TUREK, V. 2008. Boionautilus gen. nov. from the Silurian of Europe and North Africa (Nautiloidea, Tarphycerida. Bulletin of Geosciences 83(2), 141-152. DOI 10.3140/bull.geosci.2008.02.141

VANĚK, J. 1999. Ordovician in the easternmost part of the Prague Basin (Úvaly and Brandýs areas) and its comparison with the Rokycany area (westernmost part of the basin). Palaeontologia Bohemiae 5(2), 5-20.

WESTERMANN, G.E.G. 1998. Life habits of nautiloids, 263-298. In SAVAZZI, E. (ed.) Functional Morphology of the Invertebrate Skeleton. John Wiley, London.

WHITEAVES, J.F. 1904. The Canadian species of Trocholites. Ottawa Naturalist 18(7), 13-18.

ZuSKOVÁ, J. 1993. Conodonts of the Klabava Formation (Early Ordovician, Prague Basin). Bulletin of the Czech Geological Survey 68(1), 31-42. 